\title{
Yi Chinese
}

National Cancer Institute

\section{Source}

National Cancer Institute. Yi Chinese. NCI Thesaurus. Code C158164.

A Chinese person from the Yi ethnic group. 